\title{
Pengaruh Kepercayaan, Kemudahan, Kualitas Informasi Terhadap Keputusan Pembelian Secara Online Pada Situs Jual Beli Tokopedia (Studi Kasus Wilayah Tangerang)
}

\author{
Melinda Agustina ${ }^{1}$ \\ Fidellis Wato Tholok ${ }^{2}$ \\ Handry ${ }^{3}$ \\ Manajemen, Universitas Buddhi Dharma, Banten, Indonesia
}

\begin{abstract}
Abstrak
Penelitian ini bertujuan untuk mengetahui pengaruh Kepercayaan, Kemudahan, Kualitas Informasi terhadap Keputusan Pembelian secara online pada situs jual beli Tokopedia (studi kasus wilayah Tangerang). Populasi penelitian adalah konsumen yang pernah melakukan pembelian secara online di situs Tokopedia. Sampel berjumlah 100 orang dengan metode purposive sampling. Pengumpulan data dilakukan dengan menggunakan kuesioner. Data dianalisis menggunakan analisis regresi linier berganda dengan menggunakan program SPSS. Hasil penelitian menunjukan bahwa Kepercayaan berpengaruh positif dan signifikan terhadap Keputusan Pembelian, Kemudahan berpengaruh positif dan signifikan terhadap Keputusan Pembelian, Kualitas Informasi berpengaruh positif dan signifikan terhadap Keputusan Pembelian. Berdasarkan hasil uji hipotesis diperoleh bahwa

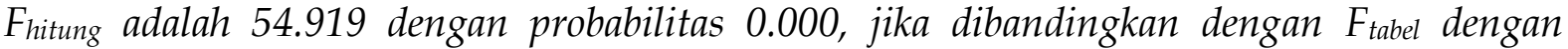
tingkat signifikan 0.05 diperoleh nilai sebesar 2.70, sehingga $F_{\text {hitung }}>F_{\text {tabel }}(54.919>2.70)$. Dengan demikian Ho ditolak dan Ha diterima, artinya terdapat hubungan antara variabel Kepercayaan, Kemudahan, Kualitas Informasi terhadap Keputusan Pembelian secara online pada situs jual beli Tokopedia.
\end{abstract}

Kata Kunci : Kepercayaan, Kemudahan, Kuliats Informasi, Keputusan Pembelian 


\section{Abstract}

This study aims to determine the effect of Trust, Ease, Quality of Information on Purchase Decisions online at the Tokopedia trading site (case study in the Tangerang area). The research population is consumers who have made purchases online on the Tokopedia site. The sample was 100 people with purposive sampling method. Data collection is done using a questionnaire. Data were analyzed using multiple linear regression analysis using the SPSS program. The results show that Trust has a positive and significant effect on Purchasing Decisions, Convenience has a positive and significant effect on Purchase Decisions, Information Quality has a positive and significant effect on Purchase Decisions.

Based on the results of hypothesis testing it is obtained that Fcount is 54,919 with a probability of 0,000, when compared with Ftable with a significant level of 0.05 obtained a value of 2.70, so that Fcount> Ftable (54.919> 2.70). Thus Ho is rejected and Ha is accepted, meaning that there is a relationship between the variables of Trust, Ease, Quality of Information on Purchase Decisions online at the Tokopedia sale and purchase site.

\section{Keywords: Trust, Ease, Quality of Information, Purchase Decision}

\section{PENDAHULUAN}

Teknologi dan informasi yang ada di dunia khususnya pada era globalisasi saat ini mengalami perkembangan yang sangat pesat serta signifikan di seluruh negara yang ada di dunia, salah satunya adalah Indonesia. Di indonesia sendiri, teknologi informasi banyak sekali digunakan oleh pihak ataupun kelompok untuk menunjang setiap aktifitas serta kegiatan usaha yang mereka jalani dalam kehidupan sehari - hari. Dengan adanya kecanggihan dalam hal teknologi informasi tersebut maka sangat membantu setiap individu maupun kelompok untuk dapat melakukan sebuah komunikasi serta proses penyampaian informasi. Kemudahan yang diberikan dalam hal proses penyampaian informasi dari satu pihak kepada pihak lain secara efektif dan efisien merupakan salah satu faktor kunci mengapa teknologi informasi tersebut begitu diminati oleh masyarakat luas.

Hal inilah yang mendasari dari terciptanya sebuah jenis usaha baru yang tumbuh dan berkembang dengan cepat di berbagai negara termasuk di Indonesia saat ini dengan menggunakan media internet sebagai sarana penunjang dari kegiatan usaha ataupun bisnis tersebut yaitu berupa situs jual beli online. Dalam praktiknya secara langsung, kegiatan jual beli secara online tersebut sangat sensitif atau berkaitan erat dengan masalah kepercayaan. Hal ini dikarenakan situs jual beli online sangat memiliki perbedaan yang signifikan jika dibandingkan dengan sebuah usaha fisik pada umumnya seperti toko, supermarket, ataupun mall dimana pihak penjual dapat bertatap muka secara langsung dengan pihak pembeli.

Pada situs jual beli online ini hal tersebut berbanding terbalik dimana pihak penjual tidak dapat bertatap muka secara langsung dengan pihak pembeli, tetapi melalui media internet lah sebagai sarana untuk melakukan proses komunikasi dan kegiatan usaha jual beli tersebut. Oleh karena itu, dengan tidak bertemunya secara langsung antar pihak yang melakukan proses transaksi jual beli tersebut faktor kepercayaan mutlak menjadi prioritas yang sangat dikedepankan antar pihak 
tersebut. Faktor kemudahan pada situs jual beli online tersebut adalah dalam hal efisiensi dan efektifitas seperti menghemat waktu dan tenaga karena adanya perbedaan jarak antar lokasi. Dengan adanya situs jual beli online ini, hal - hal yang menjadi hambatan tersebut bisa diatasi dengan kemajuan teknologi internet saat ini.

Salah satu e-commerce terbesar di Indonesia adalah Tokopedia. Tokopedia hadir di tengah - tengah masyarakat sebagai situs jual beli online terbesar di Indonesia saat ini untuk memberikan sebuah kemudahan dalam melakukan kegiatan transaksi jual beli atau kegiatan usaha dengan media internet sebagai sarana penunjang segala macam aktifitas bisnis tersebut. Sebuah kemudahan ketika kita ingin membuka usaha tersebut pada situs jual beli Tokopedia ini yang sangat mudah untuk dilakukan dengan berbagai tahapan yang ada dan cara pemasaran yang baik untuk dapat dilihat, dikunjungi, serta diminati oleh calon pembeli tetntang produk apa saja yang ditawarkan. Selain itu, Tokopedia tidak hanya dapat dikunjungi melalui website saja, tetapi sudah bisa diakses dengan mengunduhnya pada layanan Play Store ataupun App Store. Begitu juga dalam hal kemudahan proses transaksi, Tokopedia sudah bekerja sama dengan bank - bank terkemuka di Indonesia dalam hal menjaga keamanan demi menekan angka kecurangan ataupun penipuan yang tidak diharapkan oleh pihak manapun yang terlibat dalam transaksi secara online tersebut.

Dalam hal kualitas informasi yang ada pada situs jual beli Tokopedia saat ini sangat baik dengan menampilkan secara detail mengenai informasi dari toko serta lokasi toko tersebut, produk apa saja yang ditawarkan dengan kategori serta spesifikasi yang berbeda antara produk yang satu dengan yang lain sehingga calon pembeli dapat menyesuaikan dengan apa yang menjadi kebutuhannya tersebut. Pada situs jaul beli Tokopedia pun disediakan forum ataupun fasilitas untuk tanya jawab antara pihak penjual dengan calon pembeli guna memberikan sebuah pemahaman ataupun penyampaian informasi tentang spesifikasi dari produk yang diperbincangkan agar dapat disesuaikan dengan kebutuhan yang diinginkan. Oleh karena itu faktor - faktor seperti kepercayaan, kemudahan, serta kualitas informasi yang terdapat pada situs jual beli online khususnya Tokopedia sangat berperan penting pada keputusan seseorang ataupun pihak dalam melakukan sebuah pembelian suatu produk.

Pada persaingan dalam era digital saat ini memang banyak sekali bermunculan situs jual beli online di seluruh dunia khususnya Indonesia. Tokopedia memiliki berbagai macam keunggulan dari para pesaingnya tersebut sehingga membuatnya berada dalam posisi puncak untuk menjadi situs jual beli online yang terbesar di Indonesia. Dengan tersedianya banyak fitur yang menarik diharapkan mampu meningkatkan kesadaran masyarakat untuk dapat mengunjungi situs dari Tokopedia tersebut. Kegiatan pemasaran yang dilakukan oleh situs jual beli Tokopedia pun sudah luas dengan memanfaatkan berbagai media sebagai sarana promosi seperti pada media cetak (surat kabar dan majalah) maupun elektronik (televisi, radio, internet, dll) guna menarik minat calon konsumen ataupun masyarakat dalam memutuskan pilihan dalam pembelian sebuah produk. 


\section{TINJAUAN PUSTAKA \\ E-Commerce}

E-commerce adalah proses dimana pembeli dan penjual melakukan pertukaran informasi, uang, dan barang melalui sarana elektronik, terutama di internet (Peter and Olson 2014). Perkembangan toko online di Indonesia saat ini semakin pesat. Hal tersebut dipengaruhi dengan meningkatnya akses teknologi berbasis internet yang dapat dilakukan melalui PC, komputer ataupun smartphone. Beberapa faktor yang mempengaruhi perkembangan toko online di Indonesia, yaitu Jumlah pengguna internet yang sangat banyak dan akan terus bertambah dari waktu ke waktu, Akses internet yang cepat dan mudah, Harga yang ditawarkan toko online yang lebih terjangkau dibandingkan toko offline, sistem pembayaran yang mudah.

\section{Kepercayaan}

Menurut (Ardiansyah 2017) Percaya atau saling mempercayai merupakan syarat utama dalam kegiatan bisnis, lebih-lebih dalam electronic-commerce yang dimasa dekat akan semakin berkembang. Menurut (Pratama 2015) Kepercayaan adalah salah satu modal utama di dalam menuju kesuksesan dari suatu bisnis termasuk juga bisnis online berbasis E-commerce. Dari definisi diatas dapat disimpulkan bahwa Kepercayaan adalah suatu cara yang dilakukan dalam memegang teguh prinsip keyakinan antara konsumen dan perusahaan dan dapat dipertanggungjawabkan segala bentuk kerahasiaan data agar menghasilkan persepsi yang positif dan berujung pada hubungan loyal antara perusahaan dengan konsumen .

Dalam transaksi secara online, kepercayaan muncul ketika salah satu pihak yang terlibat telah mendapat kepastian dari pihak lainnya, serta mau dan bisa memberikan kewajibannya. Ketika konsumen melakukan berbelanja online, hal utama yang menjadi pertimbangan seorang konsumen adalah apakah website atau situs yang menyediakan online shop dan penjual online tersebut dapat dipercaya. Kepercayaan konsumen terhadap website atau situs online shop terletak pada popularitas website atau situs online shop tersebut. Semakin popularitas suatu website atau situs online shop, maka pembeli lebih yakin dan percaya terhadap website atau situs tersebut. Kepercayaan terdiri dari 3 komponen yaitu Integritas (Integrity), Kebaikan (Benevolence), Kompetensi (Competence). (Yuniati, 2016)

1. Integritas (Integrity)

Integritas merupakan keyakinan konsumen bahwa peritel online akan mampu memberikan layanan yang terbaik untuk konsumen seperti menepati janji, berperilaku sesuai etika dan jujur.

2. Kebaikan (Benevolence)

Kebaikan merupakan keyakinan konsumen terhadap perusahaan bahwa perusahaan tidak hanya memikirkan masalah bisnis semata dengan konsumen tetapi juga memberikan perlindungan atas kepentingan konsumen.

3. Kompetensi (Competence)

Kompetensi merupakan kemampuan untuk memecahkan permasalahan yang dihadapi oleh konsumen dan memenuhi segala keperluannya. Kemampuan mengacu pada keahlian dan karakteristik yang memungkinkan suatu kelompok mempunyai pengaruh yang dominan. Dalam hal ini, bagaimana seorang penjual 
mampu untuk melayani, menyediakan, pengetahuan tentang produk, kecepatan layanan dan kualitas pelayanan.

\section{Kemudahan}

Menurut Davis dalam jurnal (Rahman, 2017) Kemudahan penggunaan (ease of use) sebagai suatu tingkatan dimana seseorang percaya bahwa komputer dapat dengan mudah dipahami. Menurut (Pratama 2015) Kemudahan dalam E-Commerce adalah dapat dengan mudah menjajakan produk mereka tersebut kepada para pengguna internet (calon konsumen). Dari definisi diatas dapat disimpulkan bahwa Kemudahan adalah suatu sikap dimana seseorang berpikir bahwa menggunakan suatu teknologi akan mengurangi usaha baik waktu dan tenaga.

Hal yang menjadi pertimbangan bagi konsumen adalah faktor kemudahan penggunaan situs online shop. Faktor kemudahan ini akan berdampak pada perilaku, yaitu semakin tinggi presepsi seseorang tentang kemudahan menggunakan sistem, semakin tinggi pula tingkat pemanfaatan teknologi informasi. Kemudahan pengguna dapat diartikan sebagai konsumen percaya bahwa dalam menggunakan atau bertransaksi secara online pada situs jual beli akan mengurangi usaha baik waktu dan tenaga. Menurut Venkatesh dan Davis dalam (Ria Yunita Dewi, Yulianeu, Andi Tri Haryono, 2016) membagi dimensi kemudahan sebagai berikut:

a. Interaksi Individu dengan sistem yang jelas mudah dimengerti (clear and understandable)

b. Tidak dibutuhkan banyak usaha untuk berinteraksi dengan sistem tersebut (doesn't require a lot of mental effort)

c. Sistem mudah digunakan (easy to use)

\section{Kualitas Informasi}

Menurut (Winarno 2017) Informasi dapat berguna bagi pemakainya atau bisa juga tidak berguna sama sekali. Hal itu tergantung kepada kualitas informasi tersebut, informasi akan berguna apabila kualitasnya baik. Menurut Mukhtar dalam jurnal (Ria Yunita Dewi , Yulianeu, Andi Tri Haryono, 2016) Informasi yang disajikan pada online shop sebaiknya mencakup informasi berkaitan dengan produk dan jasa yang ada pada online shop. Dari definisi diatas dapat disimpulkan bahwa Kualitas Informasi adalah Informasi yang diberikan oleh penjual kepada konsumen secara jelas dan akurat.

Informasi sebaiknya berguna dan relevan dalam memprediksi kualitas dan kegunaan produk atau jasa. Untuk memuaskan kebutuhan informasi konsumen atau pembeli online, informasi produk dan jasa harus up-to-date, membantu konsumen atau pembeli online dalam membuat keputusan, konsisten, dan mudah dipahami. Semakin berkualitas informasi dari situs atau website jual beli online, maka semakin tinggi minat dari konsumen dalam melakukan pembelian secara online pada situs tersebut.

\section{Keputusan Pembelian}

Menurut (Sumarwan 2013) Keputusan pembelian adalah keputusan konsumen mengenai apa yang dibeli, apakah membeli atau tidak, dimana membeli dan bagaimana cara pembayarannya. Menurut Schiffman dan Kanuk dalam jurnal (Ria Yunita Dewi, Yulianeu, Andi Tri Haryono, 2016) Keputusan pembelian adalah pemilihan dari dua atau lebih alternatif pilihan artinya bahwa seseorang dapat 
membuat keputusan, haruslah tersedia beberapa alternatif pilihan. Dari beberapa devisini diatas dapat disimpulkan bahwa Keputusan Pembelian adalah proses yang dilakukan konsumen dalam memilih satu atau lebih produk dan mengambil sebuah keputusan sebelum melakukan pembelian.

\section{METODE PENELITIAN}

\section{Populasi}

(Sugiyono, Metode Penelitian Kuantitatif, Kualitatif, dan R\&D 2011, 117) menyatakan populasi adalah wilayah generalisasi yang terdiri dari atas objek atau subyek yang mempunyai kualitas dan karakteristik tertentu yang ditetapkan oleh peneliti untuk dipelajari dan kemudian ditarik kesimpulannya. Populasi dari penelitian ini adalah masyarakat yang menggunakan situs $e$-commerce Tokopedia.

\section{Sampel}

(Sugiyono, Metode Penelitian Kuantitatif, Kualitatif, dan R\&D 2011, 81) menyatakan sampel adalah bagian dari jumlah dan karakteristik yang dimiliki oleh populasi tersebut. Sampel dalam penelitian ini ditujukan kepada masyarakat yang menggunakan situs e-commerce Tokopedia yang tinggal didaerah Tangerang. Peneliti menggunakan purposive sampling dalam pengambilan sampel dimana teknik sampling digunakan oleh peneliti yang mempunyai pertimbangan-pertimbangan tertentu dalam pengambilan sampelnya.

\section{Teknik Pengumpulan Data}

Data yang akan digunakan dalam penelitian ini akan dikumpulkan dengan melalui survei kepada masyarakat di wilayah Tangerang. Survei tersebut dilakukan dengan menggunakan kuesioner kepada masyarakat di wilayah Tangerang dan yang menjadi sampel dari penelitian ini adalah masyarakat yang pernah melakukan pembelian di Tokopedia.

\section{HASIL DAN PEMBAHASAN}

\section{Regresi Berganda}

Analisis regresi ini digunakan untuk menghitung besarnya pengaruh antara variabel bebas, yaitu kepercayaan (X1), kemudahan (X2) danKualitas Informasi (X3) terhadap variabel terikat yaitu Keputusan Pembelian (Y).

\begin{tabular}{|l|l|}
\hline Variabel & $\begin{array}{l}\text { Unstandardized } \\
\text { Coefficients }\end{array}$ \\
\hline Constant & .494 \\
\hline Kepercayaan & .401 \\
\hline Kemudahan & .221 \\
\hline Kualitas Informasi & .267 \\
\hline
\end{tabular}

Berdasarkan pada Tabel diatas didapatkan persamaan regresi sebagai berikut:

Keputusan Pembelian $=0.494+0.401 X_{1}+0.221 X_{2}+0.267 X_{3}$

Keputusan Pembelian Online akan meningkat untuk setiap tambahan X1 (kepercayaan), Jadi apabila kepercayaan mengalami peningkatan, maka Keputusan Pembelian Online akan meningkat dengan asumsi variabel yang lainnya dianggap konstan. 
- Keputusan Pembelian Online akan meningkat untuk setiap tambahan X2 (kemudahan), Jadi apabila kemudahan mengalami peningkatan, maka Keputusan Pembelian Online akan meningkat dengan asumsi variabel yang lainnya dianggap konstan.

- Keputusan Pembelian Online akan meningkat untuk setiap tambahan X3 (Kualitas Informasi), Jadi apabila kualitas informasi mengalami peningkatan, maka Keputusan Pembelian Online akan meningkat dengan asumsi variabel yang lainnya dianggap konstan.

Berdasarkan interpretasi di atas, dapat diketahui besarnya kontribusi variabel bebas terhadap variabel terikat, antara lain kepercayaan sebesar 0,401, kemudahan sebesar 0,221, Kualitas Informasi sebesar 0.267. Sehingga dapat disimpulkan bahwa kepercayaan, kemudahan dan kualitas informasi mempunyai arah hubungan yang positif terhadap Keputusan Pembelian Online. Dengan kata lain, apabila bahwa kepercayaan, kemudahan, dan kualitas informasi meningkat maka akan diikuti peningkatan Keputusan Pembelian Online.

\section{Uji Multikolonieritas}

Uji multikolonieritas bertujuan untuk menguji apakah model regresi ditemukan adanya korelasi antar variabel bebas (independen).

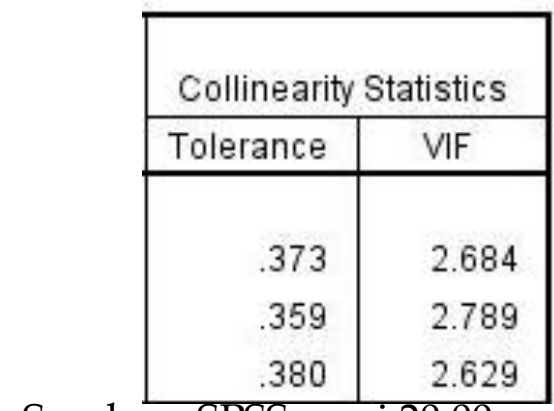

Sumber : SPSS versi 20.00

Pada tabel diatas nilai Tolerance menunjukan tidak ada variabel independen yang memiliki nilai Tolerance lebih dari 0.10 yang berarti tidak ada korelasi antar variabel independen yang nilainya lebih dari 95\%. Hasil perhitungan nilai VIF (Variance Inflation Factor) juga menunjukkan tidak ada variabel independen yang memiliki nilai VIF kurang dari 10. Jadi dpat disimpulkan bahwa tidak ada multikolonieritas antar variabel independen dalam model regresi.

\section{Uji Autokorelasi}

Uji autokorelasi bertujuan menguji apakah dalam model regresi linier ada korelasi antara kesalahan pengganggu pada periode $t$ dengan kesalahan pengganggu pada periode $t$ sebelumnya.

\begin{tabular}{|l|}
\hline Durbin-Watson \\
\hline 2.217 \\
\hline
\end{tabular}

Dari tabel diatas dapat dilihat bahwa nilai dari DW sebesar 2.217. Nilai akan dibandingkan dengan nilai tabel signifikans 5\% dengan n 100 dan jumlah variabel independent $(\mathrm{k}=3)$. 
$\mathrm{dL}=1.6131$

$\mathrm{dU}=1.7364$

Karena DW lebih besar dU dan kurang dari 4 - dU (2.263), maka : $1.7364<2.217<$ 2.263

Dapat disimpulkan bahwa Tidak ada autokorelasi.

Uji Heteroskedastistas Dengan Metode Glesjer

Coefficients $^{\mathrm{a}}$

\begin{tabular}{|c|c|c|c|c|c|c|}
\hline \multirow[b]{2}{*}{ Mode } & & \multicolumn{2}{|c|}{ Unstandardized Coefficients } & \multirow{2}{*}{$\begin{array}{c}\begin{array}{c}\text { Standardized } \\
\text { Coefficients }\end{array} \\
\text { Beta }\end{array}$} & \multirow[b]{2}{*}{1} & \multirow[b]{2}{*}{ Sig. } \\
\hline & & $B$ & Std. Error & & & \\
\hline \multirow[t]{4}{*}{1} & (Constant) & .248 & .168 & & 1.482 & .142 \\
\hline & Kepercayaan & .002 & .060 & .006 & .035 & .972 \\
\hline & Kemudahan & .007 & .058 & .021 & .124 & .901 \\
\hline & Kualitas Informasi & -.022 & .060 & -.059 & -.357 & .722 \\
\hline
\end{tabular}

a. Dependent Variable: abs_res

Sumber : SPSS versi 20.00

Berdasarkan tabel diatas uji heteroskedastistas dengan metode Glesjer diperoleh nilai Signifikan sebesar 0.972 (X1), 0.901 (X2), 0.722 (X3), dimana nilai tersebut lebih besar 0.05, sehingga dapat disimpulkan data tidak terjadi masalah heteroskedastistas.

Uji Normalitas dengan Metode One-Sample Kolmogorov-Smirnov Test

One-Sample Kolmogorov-Smirnov Test

\begin{tabular}{|c|c|c|}
\hline & & $\begin{array}{l}\text { Unstandardiz } \\
\text { ed Residual }\end{array}$ \\
\hline$N$ & & 100 \\
\hline \multirow[t]{2}{*}{ Normal Parameters ${ }^{a, b}$} & Mean & $0 \mathrm{E}-7$ \\
\hline & Std. Deviation & .24399671 \\
\hline \multirow[t]{3}{*}{ Most Extreme Differences } & Absolute & .059 \\
\hline & Positive & .044 \\
\hline & Negative & -.059 \\
\hline Kolmogorov-Smirnov Z & & .592 \\
\hline Asymp. Sig. (2-tailed) & & .874 \\
\hline
\end{tabular}

a. Test distribution is Normal.

b. Calculated from data.

Pada tabel diatas menunjukan nilai Asymp. Sig sebesar 0.874 lebih besar dari 0.05, maka dapat disimpulkan bahwa data residual berdistribusi normal.

\section{Koefisien Determinasi $\left(\mathbf{R}^{2}\right)$}

Untuk mengetahui besar kontribusi variabel bebas (kemudahan(X1) dan kepercayaan(X2) terhadap variabel terikat (Keputusan Pembelian Online)) digunakan nilai R2. 
Model Summary

\begin{tabular}{|l|c|r|r|r|}
\hline Model & R & R Square & $\begin{array}{c}\text { Adjusted R } \\
\text { Square }\end{array}$ & $\begin{array}{c}\text { Std. Error of } \\
\text { the Estimate }\end{array}$ \\
\hline 1 & $.795^{\mathrm{a}}$ & .632 & .620 & .24778 \\
\hline
\end{tabular}

a. Predictors: (Constant), Kualitas Informasi, Kepercayaan, Kemudahan

\section{b. Dependent Variable: Keputusan Pembelian}

Sumber : SPSS versi 20.00

a. Kolom $\mathrm{R}$ square $\left(\mathrm{R}^{2}\right)$ menunjukan angka $\mathrm{R}$ aquare adalah 0.632. Angka tersebut digunakan untuk mengetahui besarnya pengaruh Kepercayaan, Kemudahan, Kualitas Informasi terhadap keputusan pembelian dengan cara menghitung koefisien determinasi $\mathrm{r}^{2} \times 100 \%$ atau $0.632 \times 100 \%=63.2 \%$. Hal tersebut menunjukan bahwa pengaruh Kepercayaan, Kemudahan, Kualitas Informasi terhadap keputusan pembelian sebesar $63.2 \%$, dan sisanya sebesar $36.8 \%(100-63.2 \%)$ dipengaruhi oleh variabel lain diluar variabel penelitian yang diteliti.

b. Kolom $\mathrm{R}$ menunjukan bahwa angka koefisien korelasi sebesar 0.795. Hal tersebut menunjukan tingkat hubungan antara variabel Kuat.

c. Nilai Adjusted R Square sebesar 0.620 mendekati 1, artinya variabel independen yaitu Kepercayaan, Kemudahan, Kualitas Informasi dapat berpengaruh secara kuat terhadap variabel dependen yaitu Keputusan Pembelian.

d. Standart Error of Estimate (SEE) sebesar 0.24778, semakin kecil nilai SEE akan membuat model regresi semakin tepat dalam memprediksi Keputusan Pembelian.

\section{UJI HIPOTESIS}

\section{Uji T}

Uji T bertujuan untuk mengetahui pengaruh variabel-variabel bebas secara parsial terhadap variabel terikatnya. Kriteria pengujian $t_{\text {tabel }}$

1. Jika nilai $t_{\text {hitung }}>t_{\text {tabel }}$ maka Ho ditolak dan Ha diterima

2. Jika nilai thitung $<t_{\text {tabel }}$ maka Ha ditolak dan Ho diterima

\begin{tabular}{|l|l|l|}
\hline Variabel & $\mathrm{t}$ & Sig \\
\hline Kepercayaan & 3.822 & .000 \\
\hline Kemudahan & 2.208 & .030 \\
\hline Kualitas Informasi & 2.548 & .012 \\
\hline
\end{tabular}

a. Dari hasil output SPSS diketahui nilai thitung untuk Kepercayaan adalah sebesar 3.822, dengan nilai probabilitas jauh lebih kecil dari 0.05. Dengan menggunakan tabel distribusi normal $\mathrm{t}$ dan menggunakan tingkat keyakinan a 5\% serta derajat kebebasan degree of freedom (df) n-3 atau $100-3=97$, maka 
diperoleh nilai distribusi $t_{\text {tabel }}$ sebesar 1.660. Dapat dilihat bahwa $t_{\text {hitung }}$ lebih besar dari $t_{\text {tabel }}(3.822>1.660)$ Sehingga Ho ditolak dan Ha diterima. Hal ini dapat disimpulkan bahwa terdapat hubungan signifikan antara variabel X1 (Kepercayaan) dengan variabel Y (Keputusan Pembelian secara online pada situs jual beli Tokopedia).

b. Dari hasil output SPSS diketahui nilai thitung untuk Kemudahan adalah sebesar 2.208, dengan nilai probabilitas jauh lebih kecil dari 0.05. Dengan menggunakan tabel distribusi normal $\mathrm{t}$ dan menggunakan tingkat keyakinan a $5 \%$ serta derajat kebebasan degree of freedom (df) n-3 atau $100-3=97$, maka diperoleh nilai distribusi $t_{\text {tabel }}$ sebesar 1.660. Dapat dilihat bahwa $t_{\text {hitung }}$ lebih besar dari $t_{\text {tabel }}(2.208>1.660)$ Sehingga Ho ditolak dan Ha diterima. Hak ini dapat disimpulkan bahwa terdapat hubungan signifikan antara variabel X2 (Kemudahan) dengan variabel Y (Keputusan Pembelian secara online pada situs jual beli Tokopedia).

c. Dari hasil output SPSS diketahui nilai thitung untuk Kualitas Informasi adalah sebesar 2.548, dengan nilai probabilitas jauh lebih kecil dari 0.05. Dengan menggunakan tabel distribusi normal $t$ dan menggunakan tingkat keyakinan a 5\% serta derajat kebebasan degree of freedom (df) n-3 atau $100-3=97$, maka diperoleh nilai distribusi $t_{\text {tabel }}$ sebesar 1.660. Dapat dilihat bahwa thitung lebih besar dari $t_{\text {tabel }}(2.548>1.660)$ Sehingga Ho ditolak dan Ha diterima. Hak ini dapat disimpulkan bahwa terdapat hubungan signifikan antara variabel X3 (Kualitas Informasi) dengan variabel Y (Keputusan Pembelian secara online pada situs jual beli Tokopedia).

\section{Uji F}

Uji $\mathrm{F}$ bertujuan untuk mengetahui pengaruh variabel-variabel bebas secara simultan terhadap variabel terikatnya.

Untuk pengujian dapat dilakukan dengan membandingkan besarnya nilai $\mathrm{F}$ penelitian dengan F pada tabel dengan cara Menggunakan kriteria hipotesis sebagai berikut:

a. Jika $\mathrm{F}$ penelitian $>$ nilai $\mathrm{F}$ tabel, maka $\mathrm{H}_{0}$ ditolak.

b. Jika $\mathrm{F}$ penelitian < nilai $\mathrm{F}$ tabel, maka $\mathrm{H}_{0}$ diterima.

ANOVA $^{\mathrm{a}}$

\begin{tabular}{|ll|r|r|r|r|l|}
\hline \multicolumn{1}{|c|}{} & \multicolumn{1}{c|}{$\begin{array}{c}\text { Sum of } \\
\text { Squares }\end{array}$} & \multicolumn{1}{c|}{ df } & Mean Square & \multicolumn{1}{c|}{ F } & Sig. \\
\hline 1 & Regression & 10.115 & 3 & 3.372 & 54.919 & $.000^{\circ}$ \\
& Residual & 5.894 & 96 & .061 & & \\
& Total & 16.009 & 99 & & & \\
\hline
\end{tabular}

a. Dependent Variable: Keputusan Pembelian

b. Predictors: (Constant), Kualitas Informasi, Kepercayaan, Kemudahan

Sumber : SPSS versi 20.00 
Dari tabel ANOVA diatas dapat dilihat bahwa $F_{\text {hitung }}$ adalah 54.919 dengan probabilitas 0.000, jika dibandingkan dengan $\mathrm{F}_{\text {tabel }}$ dengan tingkat signifikan 0.05 diperoleh nilai sebesar 2.70, sehingga $F_{\text {hitung }}>F_{\text {tabel }}(54.919>2.70)$. Dengan demikian Ho ditolak dan Ha diterima, artinya terdapat pengaruh secara simultan antara variabel Kepercayaan, Kemudahan, Kualitas Informasi terhadap Keputusan Pembelian secara online pada situs jual beli Tokopedia.

\section{PEMBAHASAN}

\section{Pengaruh Kepercayaan terhadap Keputusan Pembelian}

Hasil penelitian membuktikan bahwa terdapat pengaruh positif dan signifikan antara variabel Kepercayaan terhadap keputusan pembelian. Berdasarkan hasil penelitian melalui hasil uji $\mathrm{t}$ dengan tingkat signifikan 0.000 menunjukan bahwa signifikan uji $\mathrm{t}$ lebih kecil dari 0.05 dan koefisien regresi mempunyai nilai positif sebesar 0.401 . Sedangkan nilai thitung yang diperoleh sebesar 3.822 dimana lebih besar dari nilai tabel $(3.822>1.660)$.

Berdasarkan hasil tersebut maka hipotesis yang menyatakan "Kepercayaan berpengaruh terhadap Keputusan Pembelian" adalah terbukti atau dapat diterima. Adanya pengaruh yang signifikan menunjukan bahwa semakin tinggi tingkat kepercayaan konsumen dalam menggunakan situs jual beli Tokopedia maka keputusan pembelian juga akan semakin meningkat.

\section{Pengaruh Kemudahan terhadap Keputusan Pembelian}

Hasil penelitian menunjukan terdapat pengaruh positif dan signifikan antara variabel kemudahan terhadap keputusan pembelian. Berdasarkan hasil penelitian melalui hasil uji $\mathrm{t}$ dengan tingkat signifikan 0.030 menunjukan bahwa signifikan uji $\mathrm{t}$ lebih kecil dari 0.05 dan koefisien regresi mempunyai nilai positif sebesar 0.221. Sedangkan nilai $t_{\text {hitung }}$ yang diperoleh sebesar 2.208 dimana lebih besar dari nilai tabel $(2.208>1.660)$.

Berdasarkan hasil tersebut maka hipotesis yang menyatakan "Kemudahan berpengaruh terhadap Keputusan Pembelian" adalah terbukti atau dapat diterima. Adanya pengaruh yang signifikan menunjukan bahwa semakin tinggi tingkat kemudahan dalam penggunaan situs Tokopedia maka keputusan pembelian juga akan semakin meningkat.

\section{Pengaruh Kualitas Informasi terhadap Keputusan Pembelian}

Hasil penelitian menunjukan terdapat pengaruh positif dan signifikan antara variabel kualitas informasi terhadap keputusan pembelian. Berdasarkan hasil penelitian melalui hasil uji $t$ dengan tingkat signifikan 0.012 menunjukan bahwa signifikan uji $\mathrm{t}$ lebih kecil dari 0.05 dan koefisien regresi mempunyai nilai positif sebesar 0.267. Sedangkan nilai thitung yang diperoleh sebesar 2.548 dimana lebih besar dari nilai $t_{\text {tabel }}(2.548>1.660)$.

Berdasarkan hasil tersebut maka hipotesis yang menyatakan "Kualitas Informasi berpengaruh terhadap Keputusan Pembelian" adalah terbukti atau dapat diterima.

\section{Pengaruh Kepercayaan, Kemudahan, Kualitas Informasi terhadap Keputusan Pembelian}

Hasil penelitian menunjukan terdapat pengaruh positif dan signifikan antara variabel Kepercayaan, Kemudahan, Kualitas Informasi terhadap Keputusan 
Pembelian. Berdasarkan hasil penelitian melalui uji $\mathrm{F}$ diperoleh $\mathrm{F}_{\text {hitung }}$ sebesar 54.919 dengan tingkat signifikan 0.000 , hal tersebut menunjukan bahwa nilai $F_{\text {hitung }}$ lebih besar dari $\mathrm{F}_{\text {tabel }}(54.919>2.70)$, maka hipotesis yang menyatakan "Kepercayaan, Kemudahan, Kualitas Informasi berpengaruh terhadap Keputusan Pembelian" adalah terbukti atau dapat diterima.

\section{KESIMPULAN}

Berdasarkan hasil penelitian dan pembahasan, maka dapat ditarik kesimpulan sebagai berikut:

1. Analisis hubungan atau korelasi pengaruh Kepercayaan, Kemudahan, Kualitas Informasi terhadap Keputusan Pembelian secara online pada situs jual beli Tokopedia memperoleh nilai $\mathrm{R}$ 0.795. Hasil tersebut menunjukan nilai korelasinya kuat, maka jika kepercayaan, kemudahan, kualitas informasi dilaksanakan dengan perencanaan yang baik maka akan meningkatkan keputusan pembelian secara online pada situs jual beli Tokopedia.

2. Kepercayaan berpengaruh positif dan signifikan terhadap keputusan pembelian pada situs jual beli Tokopedia. Dapat dilihat pada variabel Kepercayaan (X1) dengan nilai thitung sebesar 3.822 lebih besar dari $t_{\text {tabel }}$ sebesar 1.660, hal tersebut menunjukan bahwa Ho ditolak dan $\mathrm{Ha}$ diterima. Dengan meningkatkan kepercayaan konsumen maka akan meningkatkan pembelian pada situs jual beli Tokopedia.

3. Kemudahan berpengaruh positif dan signifikan terhadap keputusan pembelian pada situs jual beli Tokopedia. Dapat dilihat pada variabel Kemudahan (X2) dengan nilai thitung sebesar 2.208 lebih besar dari $t_{\text {tabel }}$ sebesar 1.660, hal tersebut menunjukan bahwa Ho ditolak dan Ha diterima. Semakin mudah dalam menggunakan atau mengakses situs Tokopedia, maka keputusan pembelian konsumen pada situs jual beli Tokopedia meningkat.

4. Kualitas Informasi berpengaruh positif dan signifikan terhadap keputusan pembelian pada situs jual beli Tokopedia. Dapat dilihat pada variabel Kualitas informasi (X3) dengan nilai thitung sebesar 2.548 lebih besar dari $t_{\text {tabel }}$ sebesar 1.660, hal tersebut menunjukan bahwa Ho ditolak dan Ha diterima. Semakin berkualitas informasi yang diberikan Tokopedia, kejelasan dan terperinci yang diterima oleh konsumen, maka konsumen akan semakin tertarik dan akan melakukan pembelian pada situs jual beli Tokopedia.

5. Variabel Kepercayaan (X1), Kemudahan (X2), Kualitas Informasi (X3) yang didapat nilai $F_{\text {hitung }}$ sebesar 54.919, jika dibandingkan dengan $F_{\text {tabel }}$ dengan tingkat signifikan 5\% diperoleh nilai sebesar 2.70 sehingga $F_{\text {hitung }}>F_{\text {tabel }}$ ( 54.919 $>2.70$ ). Dengan demikian Ho ditolak dan Ha diterima, artinya terdapat pengaruh secara simultan antara variabel Kepercayaan, Kemudahan, Kualitas Informasi terhadap Keputusan Pembelian secara online pada situs jual beli Tokopedia.

\section{DAFTAR PUSTAKA}

Ardiansyah, Panji. Etika Bisnis. Yogyakarta: QUADRANT, 2017.

Peter, J.Paul, and Jerry C. Olson. Perilaku Konsumen $\mathcal{E}$ Strategi Pemasaran. Jakarta: Salemba Empat, 2014.

Pratama, I Putu Agus Eka. E-Commerce, E-Business dan Mobile Commerce. Bandung: Informatika Bandung, 2015. 
Rahman, A. (2017).“Pengaruh Kemudahan Penggunaan Dan Kemanfaatan Teknologi Informasi Terhadap Minat Menggunakan Situs Jual Beli Online " ( Studi Kasus Pada Pengguna Situs Jual Beli “ Z”), 52(1).

Ria Yunita Dewi , Yulianeu, Andi Tri Haryono, E. G. (2016). Pengaruh Kepercayaan Konsumen, Kemudahan Dan Kualitas Informasi Terhadap Keputusan Pembelian Secara Online Dengan Minat Beli Sebagai Variabel Intervening (Studi Pada Pengguna Situs Jual Beli Bukalapak.Com).

Sugiyono. Metode Penelitian Kuantitatif, Kualitatif, dan RED. Bandung: Alfabeta, 2011. Sumarwan, Ujang. Pemasaran Strategik - Perspektif Value-Based Marketing $\mathcal{E}$ Pengukuran Kinerja. Bogor: PT. IPB Press, 2013.

Winarno, Wing Wahyu. Sistem Informasi Manajemen. Yogayakarta: UPP STIM YKPN, 2017.

Yuniati, T. (2016). Pengaruh Kepuasan Dan Kepercayaan Pelanggan Terhadap Loyalitas Pelanggan Auto 2000 Sungkono Surabaya. Ilmu Dan Riset Manajemen : Volume 5, Nomor 6, Juni 2016, 5. 